\title{
Coxsackievirus B Tailors the Unfolded Protein Response to Favour Viral Amplification in Pancreatic $\beta$ Cells
}

\author{
Maikel L. Colli ${ }^{a} \quad$ Flavia M. Paula ${ }^{a} \quad$ Lorella Marselli $^{b}$ Piero Marchetti ${ }^{b}$ \\ Merja Roivainen $^{c}$ Decio L. Eizirik ${ }^{a}$ Anne Op de beeck ${ }^{a}$ \\ a ULB Center for Diabetes Research, Université Libre de Bruxelles, Brussels, Belgium; ' Department of \\ Clinical and Experimental Medicine, University of Pisa, Pisa, Italy; ' $V$ Viral Infections Unit, Department of \\ Infectious Disease, National Institute for Health and Welfare, Helsinki, Finland
}

\section{Keywords}

Enterovirus - Type 1 diabetes · Endoplasmic reticulum stress $\cdot$ IRE1a $\cdot c$-Jun N-terminal kinase

\begin{abstract}
Type 1 diabetes (T1D) is an autoimmune disease characterized by islet inflammation and progressive pancreatic $\beta$ cell destruction. The disease is triggered by a combination of genetic and environmental factors, but the mechanisms leading to the triggering of early innate and late adaptive immunity and consequent progressive pancreatic $\beta$ cell death remain unclear. The insulin-producing $\beta$ cells are active secretory cells and are thus particularly sensitive to endoplasmic reticulum (ER) stress. ER stress plays an important role in the pathologic pathway leading to autoimmunity, islet inflammation, and $\beta$ cell death. We show here that group $B$ coxsackievirus (CVB) infection, a putative causative factor for T1D, induces a partial ER stress in rat and human $\beta$ cells. The activation of the PERK/ATF4/CHOP branch is blunted while the IRE1 a branch leads to increased spliced XBP1 expression and c-Jun N-terminal kinase (JNK) activation. Inter-
\end{abstract}

\section{KARGER}

E-Mail karger@karger.com www.karger.com/jin
(C) 2019 The Author(s) Published by S. Karger AG, Basel

Karger

This aticle is licensed under the Creative Comms AttibtionThis article is licensed under the Creative Commons Attribution-
NonCommercial-NoDerivatives 4.0 International License (CC BYNC-ND) (http://www.karger.com/Services/OpenAccessLicense) Usage and distribution for commercial purposes as well as any distribution of modified material requires written permission. estingly, JNK1 activation is essential for CVB amplification in both human and rat $\beta$ cells. Furthermore, a chemically induced ER stress preceding viral infection increases viral replication, in a process dependent on IRE1 a activation. Our findings show that CVB tailors the unfolded protein response in $\beta$ cells to support their replication, preferentially triggering the pro-viral IRE1a/XBP1s/JNK1 pathway while blocking the pro-apoptotic PERK/ATF4/CHOP pathway.

(c) 2019 The Author(s)

Published by S. Karger AG, Basel

\section{Introduction}

Viruses are intracellular micro-organisms that depend on the host cell to accomplish their life cycle. Viruses have co-evolved with their host and adapted to their cellular responses. Specifically, they hijack cellular machinery for their own benefit, circumvent the anti-viral cellular responses, and prevent early cell death to allow completion of the viral life cycle [1]. One of the cellular mechanisms affected by viral infection is the unfolded protein re- 
sponse (UPR). The UPR is activated in response to the endoplasmic reticulum (ER) stress caused by strong viral protein synthesis, alterations in the ER membranes, and imbalances in ER calcium concentrations [2]. The UPR aims to restore protein folding homeostasis by: (1) decreasing total protein translation and consequently the load of proteins entering the ER; (2) increasing the expression of chaperones to restore protein folding and maturation; (3) inducing the degradation of terminally misfolded proteins by the ER-associated degradation (ERAD) complex [3]. If these processes are severe and/or persistent, the UPR leads to the up-regulation of inflammation and innate immunity [3], and apoptosis of the stressed cell. The UPR is transduced via 3 main pathways triggered by transmembrane ER proteins: (1) inositol requiring ER-to-nucleus signal kinase $1 \alpha$ (IRE1 $\alpha$ ), that possesses both kinase and endonuclease activities; (2) activating transcription factor (ATF) 6; and (3) doublestranded RNA-activated kinase (PKR)-like ER kinase (PERK) [3] (Fig. 1a). The IRE1 $\alpha$ endonuclease domain catalyses the splicing of the bZIP transcription factor, XBP1, generating its active form, XBP1-spliced (XBP1s). $\mathrm{XBP} 1 \mathrm{~s}$ regulates the expression of chaperones involved in protein-folding and also that of proteins regulating the ERAD [4]. The kinase domain of IRE1 $\alpha$ can phosphorylate and activate c-Jun $\mathrm{N}$-terminal kinase (JNK), contributing to late apoptosis [5]. Activated ATF6 translocates to the Golgi where it is cleaved, releasing a transcription factor involved in the regulation of genes encoding ER chaperones [6]. The kinase PERK phosphorylates eIF2 $\alpha$, promoting global protein synthesis inhibition, but, paradoxically, stimulating the translation of specific proteins such as ATF4 [7]. ATF4 regulates the expression of genes involved in the protection against oxidative stress, but it can also induce the expression of the pro-apoptotic genes

Fig. 1. Coxsackievirus infection of pancreatic $\beta$ cells triggers the unfolded protein response (UPR) and induces apoptosis. a Cellular pathways of the UPR. The accumulation of unfolded proteins in the ER leads to the activation of 3 transmembrane proteins: IRE1 a, ATF6, and PERK. In response to ER stress, 1-ATF6 undergoes conformational change leading to its release from the ER and cleavage in the Golgi. The cytosolic domain of ATF6 is a transcription factor controlling the expression of genes encoding chaperones such as BiP; 2-PERK oligomerizes and autophosphorylates. Activation of PERK induces eIF2 $\alpha$ phosphorylation, leading to a decrease in global protein synthesis and the accumulation of the transcription factor ATF4 which regulates the expression of ATF3 and CHOP. 3-IRE1 a oligomerizes and autophosphorylates and its
CCAAT/enhancer-binding protein homologous protein (CHOP) and ATF3.

Type 1 diabetes (T1D) is an autoimmune disease characterized by the progressive destruction of insulin-producing pancreatic $\beta$ cells by auto-reactive cytotoxic T cells and locally released pro-inflammatory cytokines [8]. Epidemiological and research findings indicate an association between enterovirus infection and the onset of autoimmunity against $\beta$ cells in T1D [9]. IFIH1 encodes melanoma differentiation-associated protein 5 (MDA5), a sensor of double-stranded RNA that initiates the innate immune response against infections by RNA viruses. Polymorphisms in IFIH1 are associated with T1D. [10, 11]. Enterovirus, especially coxsackievirus B (CVB) [12], have a tropism for pancreatic $\beta$ cells, and persistent CVB infection of $\beta$ cells is detected in $60-70 \%$ of pancreases from T1D individuals compared to only $6 \%$ in non-diabetic individuals [13]. Coxsackievirus can persist in the murine pancreas by deletion of the $5^{\prime}$ genomic sequence [14], but whether these deleted forms of viral genomes are present in the pancreas of T1D patients has still to be demonstrated. The exact mechanisms leading to enterovirus-mediated $\beta$ cell dysfunction and death and to autoimmunity are still to be clarified.

ER stress plays an important role in the pathologic pathway leading to autoimmunity, islet inflammation, and $\beta$ cell death [15]. We report here that CVB infections induce ER stress in both rat and human $\beta$ cells, activating both the IRE1 $\alpha$ and PERK pathways. IRE1 $\alpha$-mediated activation of JNK1 is essential for CVB replication, while PERK pathway activation fails to induce the expected upregulation of ATF4, ATF3, and $\mathrm{CHOP}$, and the consequent death of $\beta$ cells. These observations suggest that CVB tailors the UPR in the $\beta$ cells to favour its own replication while preventing premature cell death.

RNase domain becomes active and targets XBP1 mRNA, leading to the expression of the spliced form of XBP1 (XBP1s). XBP1s is a transcription factor controlling the expression of genes involved in protein folding and degradation. $\mathbf{b}-\mathbf{k}$ INS-1E cells were infected or not with CVB5 at MOI 1 (b), MOI 5 (c-k), or MOI 20 (g), or treated with CPA $(\mathbf{g})$ and followed for different time points. b CVB5-induced apoptosis was evaluated using nuclear dyes $(n=$ 3-4). c-k The expression of the viral capsid protein (VP1), the ER stress pathway proteins (PERK/eIF2 $\alpha / \mathrm{ATF} 4 / \mathrm{ATF} 3 / \mathrm{CHOP}, \mathrm{BiP}$, and IRE1 $\alpha / \mathrm{XBP} 1 \mathrm{~s}$ ) and JNK activation (p-JNK) were evaluated by Western blot at different time points and quantified by densitometry $(n=3-4) .{ }^{*} p<0.05,{ }^{* *} p<0.01$ vs. time $0 \mathrm{~h}$ (uninfected), ANOVA. Data are mean \pm SEM.

(For figure see next page.)
Colli/Paula/Marselli/Marchetti/ Roivainen/Eizirik/Op de beeck 


\section{Material and Methods}

\section{Cells Culture}

The rat pancreatic $\beta$ cell line, INS-1E (a kind gift from Dr. C. Wollheim, Centre Médical Universitaire, Geneva, Switzerland) was cultured in medium containing RPMI 1640 GlutaMAX-I, 5\% heat-inactivated FBS (Gibco, Thermo Fisher Scientific, Waltham, MA, USA), $10 \mathrm{~mm}$ HEPES, $1 \mathrm{~mm}$ Na-pyruvate and $50 \mu \mathrm{M}$ 2-mer- captoethanol [16]. The experiments were performed in INS-1E cells (passages 60-72) after 48-72 $\mathrm{h}$ of plating.

The human pancreatic $\beta$ cell line, EndoC- $\beta \mathrm{H} 1$ (kindly provided by Dr. R. Scharfmann, Centre de Recherche de l'Institut du Cerveau et de la Moelle Épinière, Paris, France), was cultured in plates pre-coated with Matrigel-fibronectin (100 and $2 \mathrm{mg} / \mathrm{mL}$, respectively) in DMEM containing $5.6 \mathrm{mM}$ glucose, $2 \%$ fatty acid-free BSA, $50 \mu \mathrm{M} 2$-mercaptoethanol, $10 \mathrm{~mm}$ nicotinamide, $5.5 \mu \mathrm{g} / \mathrm{mL}$
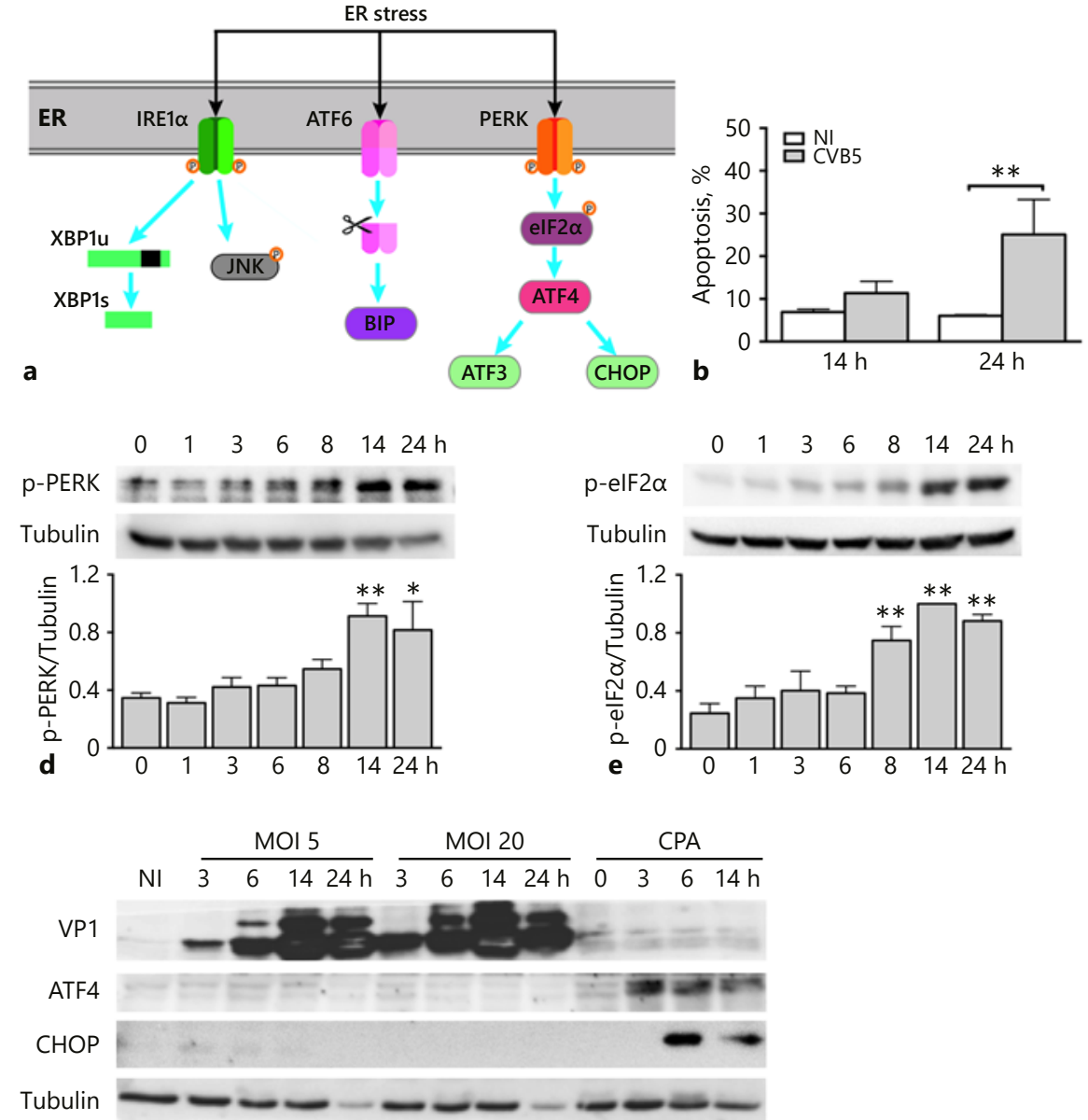

g

$\begin{array}{llllllll}0 & 1 & 3 & 6 & 8 & 14 & 24 \mathrm{~h}\end{array}$

$\begin{array}{llllllll}0 & 1 & 3 & 6 & 8 & 14 & 24 \mathrm{~h}\end{array}$
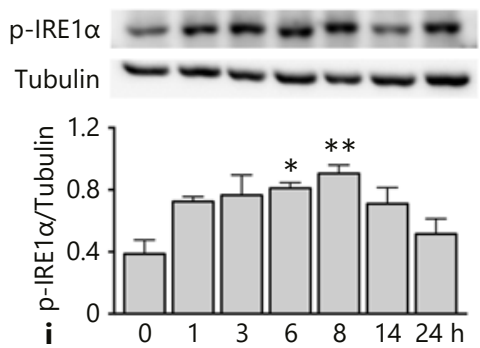

XBP1s $--\cdots=$

Tubulin

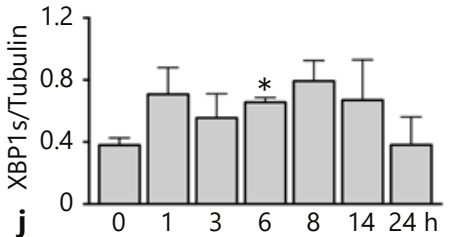

$\begin{array}{lllllll}0 & 1 & 3 & 6 & 8 & 14 & 24 \mathrm{~h}\end{array}$
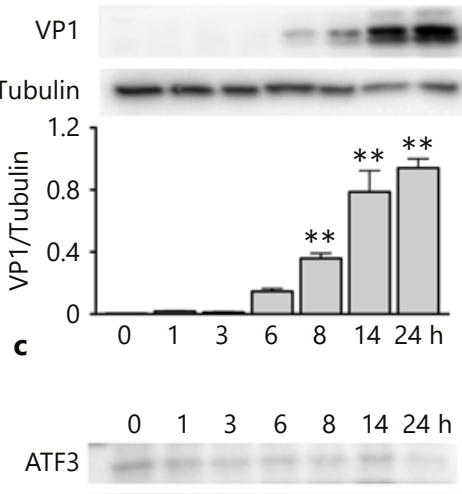

Tubulin $---\infty-\cdots$
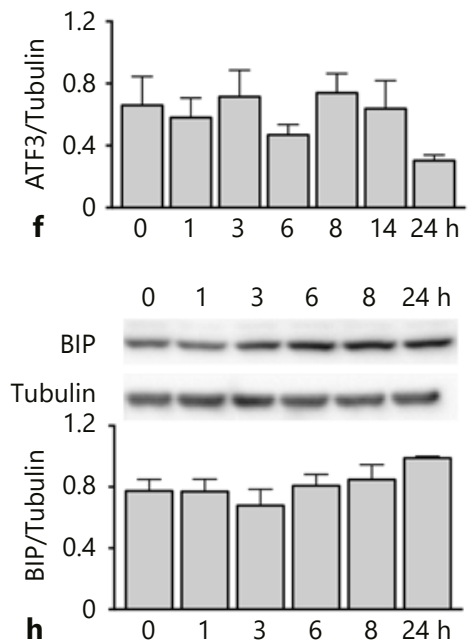

$\begin{array}{lllllll}0 & 1 & 3 & 6 & 8 & 14 & 24\end{array}$
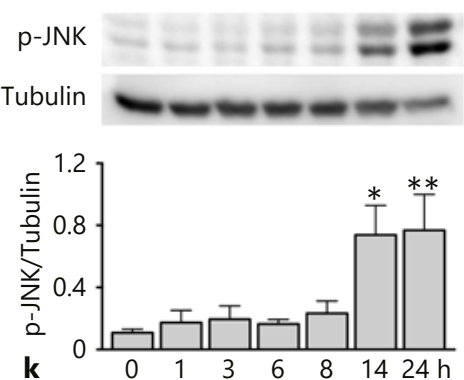

CVB Tailors UPR in Pancreatic $\beta$ Cells to Favour Viral Amplification
J Innate Immun 2019;11:375-389

DOI: $10.1159 / 000496034$ 
transferrin, $6.7 \mathrm{ng} / \mathrm{mL}$ selenite, $100 \mathrm{U} / \mathrm{mL}$ penicillin, and $100 \mu \mathrm{g} /$ $\mathrm{mL}$ streptomycin [17]. EndoC- $\beta \mathrm{H} 1$ cells (passages $66-75)$ were used for the experiments after $72 \mathrm{~h}$ of plating as described [18].

Isolation of human islets was performed by collagenase digestion and density-gradient purification [19]. The isolated islets were cultured in M199 medium containing $5.5 \mathrm{mM}$ glucose during shipment to Brussels. Upon arrival (1-5 days after isolation), the islets were left to recover overnight. The next day, they were dispersed and cultured in Ham's F-10 medium containing $6.1 \mathrm{~mm}$ glucose, 2 mM GlutaMAX, $50 \mathrm{~mm}$ 3-isobutyl-1-methylxanthine, 1\% fatty acid-free BSA, 10\% FBS, $50 \mathrm{mg} / \mathrm{mL}$ streptomycin, and $50 \mathrm{U} / \mathrm{mL}$ penicillin. The proportion of $\beta$ cells in each preparation was evaluated by immunocytochemistry for insulin [20]. During the transfection of small interfering (si)RNAs, cells were cultured in the usual medium except that the antibiotics and BSA were removed.

\section{Viral Infection}

The prototype strains of enterovirus (CVB5/Faulkner; CBV4/ JVB, CVB1/ Conn-5) were obtained from ATCC. These viruses were passaged in GMK cells. The identity of the enterovirus was confirmed by a plaque neutralization assay with type-specific anti-sera.

Cells were infected with the indicated multiplicity of infection (MOI) of the virus preparation in medium without FBS. After adsorption for $2 \mathrm{~h}$ at $37^{\circ} \mathrm{C}$, the inoculum virus was removed, and the cells were washed twice with medium. Culture medium containing FBS was then added to the plates and the virus was allowed to replicate for the indicated time periods. Viability assays were performed $24 \mathrm{~h}$ post-infection in CVB4- and CVB5-infected $\beta$ cells at a MOI of 1 in INS-1E and a MOI of 5 in EndoC- $\beta$ H1 cells, aiming to reach a cytopathogenic effect of around $30-50 \%$. The viral strain CVB1 is particularly cytopathogenic to the human cell line EndoC$\beta \mathrm{H} 1$ (100\% mortality at MOI $124 \mathrm{~h}$ post-infection, data not shown), so the MOI 0.1 was used to reach $50 \%$ cell viability. CVB1 was not used in INS-1E because it was previously demonstrated that this serotype does not replicate in rat cells [21].

\section{Viral Titration}

Cells infected with coxsackievirus were frozen in their medium and then submitted to 3 cycles of thaw and freeze for viral release. Total infectivity was evaluated using end-point dilutions in microwell cultures of GMK cells. Cytopathic effects were read on day 6 by microscopy, and $50 \%$ tissue infection dose titers were calculated using the Kärber formula [22]. The described relative viral titers are the ratio between the viral titers obtained in the treated condition and those obtained under the control condition.

\section{RNA Interference}

The siRNAs used were: Allstars Negative Control siRNA (siCTL, Qiagen, Venlo, The Netherlands), and rat JNK1 (siJNK1) [23], rat JNK2 (siJNK2) [24], and rat IRE1 $\alpha$ (siIRE1 $\alpha$ ), all from Invitrogen, Carlsbad, CA, USA [25]. The protocol for siRNA transfection was previously validated using a FITC-coupled siRNA (siGLO Green Transfection Indicator, Thermo Scientific, Chicago, IL, USA). Functional studies demonstrated that control siRNA does not affect gene expression or insulin release [26]. In brief, the transfection was performed overnight with $30 \mathrm{nM}$ of siRNA using Lipofectamine RNAiMAX (Invitrogen) according to the manufacturer's instructions [26]. After a recovery period of $48-72 \mathrm{~h}$, the cells were infected with different coxsackieviruses (CVB4 and CVB5), as described above.

\section{Cell Treatment and JNK Inhibition}

The JNK inhibitors SP600125 (Sigma-Aldrich) and JNK inhibitor V (Calbiochem, Darmstadt, Germany) were prepared in DMSO and used at concentrations of 10 and $5 \mu \mathrm{M}$, respectively. We have previously shown that this concentration induces specific JNK inhibition [27]. Since the JNK activation was not observed early during viral infection, SP600125, JNK inhibitor V, or DMSO alone (control) was added to the cell medium at the moment of the viral infection and maintained until the end of the experiment.

The chemical chaperone TUDCA (Calbiochem) was dissolved in water and used at a final concentration of $125 \mu \mathrm{M}$, based on previous dose-response experiments [18]. The cells were pre-treated for $24 \mathrm{~h}$ with TUDCA, and the drug was maintained during the entire treatment.

Tunicamycin (Sigma-Aldrich) was prepared in DMSO and used at the indicated concentrations. Cells were pre-treated with tunicamycin or DMSO alone (control) for $8 \mathrm{~h}$ before CVB infection, but the drug was not maintained after infection. In initial experiments, we performed dose-response studies to choose a concentration of tunicamycin that induces ER stress markers with minimal toxicity. Based on the dose-response assay presented in online supplementary S1 Figure (for all online suppl. material, see www.karger.com/doi/10.1159/000496034), 0.1 and $0.25 \mu \mathrm{g} / \mathrm{mL}$ tunicamycin induced the ER stress markers $\mathrm{BiP}$ and $\mathrm{XBP} 1 \mathrm{~s}$, with no increase in $\beta$ cell death. We thus selected 0.1 and $0.25 \mu \mathrm{g} / \mathrm{mL}$ tunicamycin for the subsequent experiments.

Cells were exposed to the pro-inflammatory cytokines IL- $1 \beta$ $(10 \mathrm{U} / \mathrm{mL})$ and IFN- $\gamma(100 \mathrm{U} / \mathrm{mL})$ (R\&D Systems, Abingdon, UK) in order to evaluate JNK activation. Cyclopiazonic acid $(12.5 \mu \mathrm{M})$ or thapsigargin $(1 \mu \mathrm{M})$ (Sigma-Aldrich) was used as a positive control for UPR markers [18].

\section{Assessment of Cell Viability}

The cells were stained with the DNA-binding dyes propidium iodide (PI), $5 \mu \mathrm{g} / \mathrm{mL}$, and Hoechst 33342 (HO), $5 \mu \mathrm{g} / \mathrm{mL}$, (Sigma). The number of viable, apoptotic, and necrotic cells was determined by 2 independent observers, one of them unaware of sample identity. The agreement among observers counting was $>90 \%$. In each experimental condition, at least 600 cells were counted. Results are presented as percentage of apoptosis, calculated as number of apoptotic cells/total number of cells $\times 100$, or as percentage of total cell death, calculated as number of apoptotic plus necrotic cells/ total number of cells $\times 100$. This method has been validated for use in $\beta$ cells by systematic comparison with different techniques including electron microscopy, cleavage of the effector caspase 3 , and DNA laddering $[27,28]$. In selected experiments, apoptosis was confirmed by activation (cleavage) of caspase 3 by Western blot.

\section{$m R N A$ Extraction and Real-Time PCR}

mRNA was extracted from cells with the Dynabeads mRNA DIRECT $^{\text {TM }}$ kit (Invitrogen Dynal, Oslo, Norway). The material obtained was then reverse-transcribed to generate its complementary (c)DNA [28]. cDNA was amplified by a real-time PCR reaction [28], using SYBR Green fluorescence on a LightCycler instrument (Roche, Mannheim, Germany) and correlated to a standard curve [29]. Gene expression was corrected for the housekeeping gene, GAPDH. The values are normalized by the highest value of each experiment considered as 1. GAPDH expression is not modified by viral infection of $\beta$ cells [30]. The sequences of the primers for VP1 and GAPDH were described in [30]. 

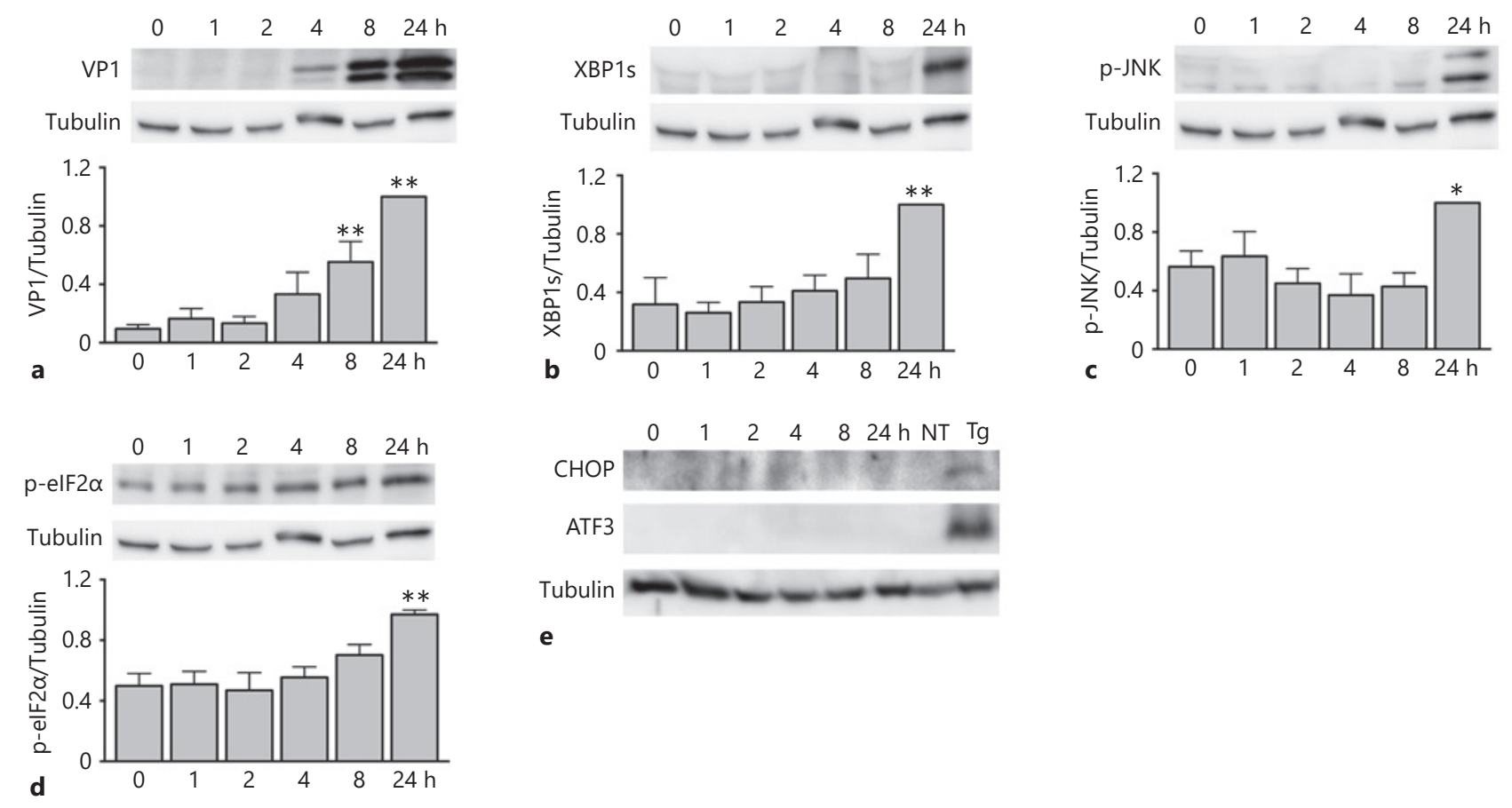

Fig. 2. Infection of the human pancreatic $\beta$ cell line EndoC- $\beta \mathrm{H} 1$ with CVB5 activates the IRE1 $\alpha$ pathway. a-e EndoC- $\beta \mathrm{H} 1$ cells were infected with CVB5 at MOI 5 or treated with thapsigargin (e) and the protein expression of the viral capsid protein (VP1), ER stress markers (p-eIF2 $\alpha, \mathrm{XBP} 1 \mathrm{~s}, \mathrm{ATF} 3$, and CHOP) and JNK phos-

\section{Western Blot Analysis}

For protein evaluation, the cells were washed once with cold PBS, and directly lysed with either Laemmli buffer (25 mM Tris$\mathrm{HCl} \mathrm{pH}$ 6.8, 10\% glycerol, 1\% SDS, 350 mM 2-mercaptoethanol, $175 \mathrm{~mm}$ dithiothreitol, and $0.005 \%$ bromophenol blue) or Phospho lysis buffer (1\% NP40, $150 \mathrm{mM} \mathrm{NaCl}, 1 \mathrm{mM} \mathrm{CaCl}_{2}, 1 \mathrm{mM}$ $\mathrm{MgCl}_{2}$; $50 \mathrm{~mm} \mathrm{NaF}, 1 \mathrm{mM} \mathrm{Na} \mathrm{VO}_{4}, 1 \mathrm{~mm}$ PMSF, and protease inhibitor cocktail [Roche]). Equal amounts of proteins were resolved by $6-12 \%$ SDS-PAGE gel and then transferred to a nitrocellulose membrane. Immunoblot analysis was performed with antibodies against ATF4, CHOP, XBP1 (Santa Cruz Biotechnology, CA, USA), p-IRE1 $\alpha$ (Ser724) (Novus Biologicals, Minneapolis, MN, USA), BIP, phospho-JNK, total JNK, JNK1, JNK2, cleaved caspase 3, phospho-eIF2a, phospho-PERK (Cell Signaling, Danvers, MA, USA), enterovirus-specific polyclonal rabbit antiserum (KTL-510) [31], GAPDH (Trevigen, MD, USA) or a-tubulin (Sigma, Bornem, Belgium). Horseradish peroxidase-conjugated donkey anti-rabbit or anti-mouse IgG were used as secondary antibodies (Lucron Bioproducts, De Pinte; Belgium). Immunoreactive bands were detected by a Bio-Rad chemi DocTM XRS+ (Bio-Rad Laboratories) using the SuperSignal West Femto chemiluminescent substrate (Thermo Scientific). Densitometric analysis of the bands was quantified using ImageLab software (Bio-Rad Laboratories). Protein expression was corrected by the housekeeping proteins

CVB Tailors UPR in Pancreatic $\beta$ Cells to Favour Viral Amplification phorylation (p-JNK) were evaluated by Western blot at different time points and quantified by densitometry $(n=3-4) .{ }^{*} p<0.05$, ** $p<0.01$ vs. time $0 \mathrm{~h}$ (uninfected), ANOVA. Data are mean \pm SEM.

a-tubulin or GAPDH and normalized by the highest value of each experiment considered as $1 . N$ represents the number of independent experiments performed.

\section{Statistical Analysis}

Data are presented as mean \pm SEM. Comparisons were performed by two-tailed paired Student's $t$ test or ANOVA followed by Bonferroni correction as adequate using Prism software v6.0. A $p$ value $<0.05$ was considered as statistically significant.

\section{Results}

\section{Coxsackievirus Infection Induces Apoptosis and}

Activates a Partial UPR in Pancreatic $\beta$ Cells

Infection of the rat insulin-producing INS-1E cells with CVB5 [32] promoted $\beta$ cell apoptosis (Fig. 1b). In parallel, there was a progressive increase in the expression of the major capsid viral protein 1 (VP1) (Fig. 1c). Infection of INS-1E cells with CVB5 induced a $>2$-fold increase in PERK activation by 14 and 24 h (Fig. 1d), leading 
to the phosphorylation of the PERK target, eIF2 $\alpha$ (Fig. 1e). Unexpectedly, there was no induction of ATF4, ATF3, or CHOP, 3 classical ER stress proteins activated downstream of PERK/eIF2 $\alpha$ (Fig. 1f, g). On the other hand, the chemical ER stressor cyclopiazonic acid (CPA), used as positive control, up-regulated the expression of both ATF4 and CHOP (Fig. 1g). In line with these findings, there were no significant changes in BiP (a downstream protein activated by ATF6) expression after the viral infection of $\beta$ cells (Fig. 1h). On the other hand, IRE1 $\alpha$ phosphorylation increased following viral infection, peaking at $8 \mathrm{~h}$ and decreasing after $14 \mathrm{~h}$ (Fig. 1i). Viral infection led also to a parallel increase of the spliced form of XBP1 (XBP1s), indicating activation of the endoribonuclease activity of IRE1a (Fig. 1j), and JNK phosphorylation, with a peak 6 -fold activation at $14 \mathrm{~h}$ (Fig. 1k). The induction of c-jun mRNA, a transcription factor induced downstream of JNK activation [33], was detected by qRTPCR, confirming the functional impact of JNK induction (online suppl. S2 Fig.). PKR is another virus-activated kinase that activates eIF2 $\alpha$. We next silenced PKR and PERK, using previously validated siRNAs (siPKR, [12] and siPERK, [34]), and evaluated the phosphorylation of eIF2 $\alpha$ in CVB5-infected INS-1E cells. Transfection of INS-1E cells with siPERK decreased by $>50 \%$ PERK protein expression when compared to a control siRNA (siCTL) (online suppl. S3 Fig. A), while siPKR inhibited (by $80 \%$ ) the induction of PKR in CVB5-infected INS-1E (online suppl. S3 Fig. B). The silencing of PERK or PKR reduced CVB5-induced eIF2 $\alpha$ phosphorylation by 30 and $50 \%$, respectively (online suppl. S3 Fig. C), indicating that both kinases contribute to the activation of eIF2 $\alpha$ during CVB5 infection. Similar to INS-1E cells, CVB5 infection of human insulin-producing EndoC- $\beta \mathrm{H} 1$ cells (Fig. 2a) induced splicing of XBP1 (Fig. 2b), JNK activation (Fig. 2c), and eIF2 $\alpha$ phosphorylation (Fig. 2d), but no induction of the downstream proteins CHOP and ATF3 (Fig. 2e). The same unfolded protein response profile is observed in EndoC- $\beta \mathrm{H} 1$ infected by 2 other CVB serotypes associated with T1D development, namely CVB4 and CVB1 (online suppl. S4 Fig. A, B).

Taken as a whole, the findings described above in rat and human $\beta$ cells indicate that CVB5 infection induces a partial ER stress response, selectively inducing IRE1 $\alpha /$ XBP1 signalling.

\section{JNK Activation during Coxsackievirus Infection of}

Pancreatic $\beta$ Cells Is IRE1 $\alpha$-Dependent

Different viruses, including enterovirus, activate JNK [35], but the mechanisms regulating this process are not well understood. To evaluate whether coxsackievirus-induced phosphorylation of JNK is secondary to IRE1 $\alpha$ activation, we inhibited IRE1 $\alpha$ expression using a previously validated siRNA against IRE1 $\alpha$ (siIRE1 $\alpha$ ) [25]. Transfection of INS-1E cells with siIRE1a decreased IRE1a protein expression by $>80 \%$ when compared to a control siRNA (siCTL) (Fig. 3a). Transfection of siCTL or siIRE1a does not affect INS-1E viability [25]. Silencing of IRE1 $\alpha$ prevented JNK phosphorylation following viral infection of INS-1E cells (Fig. 3b). In line with these results, the chemical chaperone tauroursodeoxycholic acid (TUDCA), which alleviates ER stress [36], decreased CVB5mediated JNK activation in $\beta$ cells (Fig. 3c). Since viruses modulate their environment to favour amplification, we exposed cells to a low dose of the ER stressor tunicamycin $(0.1$ or $0.25 \mu \mathrm{g} / \mathrm{mL})$ to test whether ER stress supports viral growth. Low doses of tunicamicyn induced $\mathrm{BiP}$ and $\mathrm{XBP} 1 \mathrm{~s}$ expression in the absence of augmented cell death (Fig. 3d, e). CVB5 infection of these mildly ER-stressed cells increased cell mortality, viral protein expression, and viral titer when compared to vehicle-treated cells (Fig. 3e-g). Silencing IRE1 $\alpha$ abolished the viral-supporting effect of tunicamycin (Fig. 3h), confirming that IRE1a activation potentiates CVB5 amplification.

Inhibition of JNK Phosphorylation Reduces Pancreatic $\beta$ Cells Apoptosis and Viral Replication

IRE1 $\alpha$ promotes JNK activation via its serine/threonine kinase domain [5]. JNK activation contributes to $\beta$ cell apoptosis induced by pro-inflammatory cytokines [18], free-fatty acids [27], and the mimetic viral doublestranded RNA [37]. Two independent chemical inhibitors of JNK (SP600125 and JNK inhibitor V) were used to study its role on virus-induced $\beta$ cell apoptosis. Treatment of INS-1E cells with these inhibitors reduced SP600125 and JNK inhibitor V CVB-induced JNK phosphorylation by $>60$ and $80 \%$, respectively (Fig. $4 a$ ). Inhibition of JNK activation promoted a significant decrease in CVB5-mediated $\beta$ cell apoptosis as evaluated by nuclear dyes (Fig. 4b), and cleavage of the apoptosis effector caspase 3 (Fig. 4c). Similar results were obtained using CVB4, which has been previously identified in the pancreas of recent-onset T1D patients [38] (online suppl. S5 Fig.). JNK regulates viral replication in other cell types [39-41]. To investigate whether this is the case also in $\beta$ cells, we infected INS-1E cells with CVB5 (Fig. 4) or CVB4 (online suppl. S5 Fig.) in the presence or absence of the JNK chemical inhibitors and then measured viral titers (Fig. 4d; online suppl. S5 Fig. D) and VP1 expression (Fig. 4e; online suppl. S5 Fig. E). Prevention of JNK acti-
J Innate Immun 2019;11:375-389 DOI: $10.1159 / 000496034$
Colli/Paula/Marselli/Marchetti/ Roivainen/Eizirik/Op de beeck 

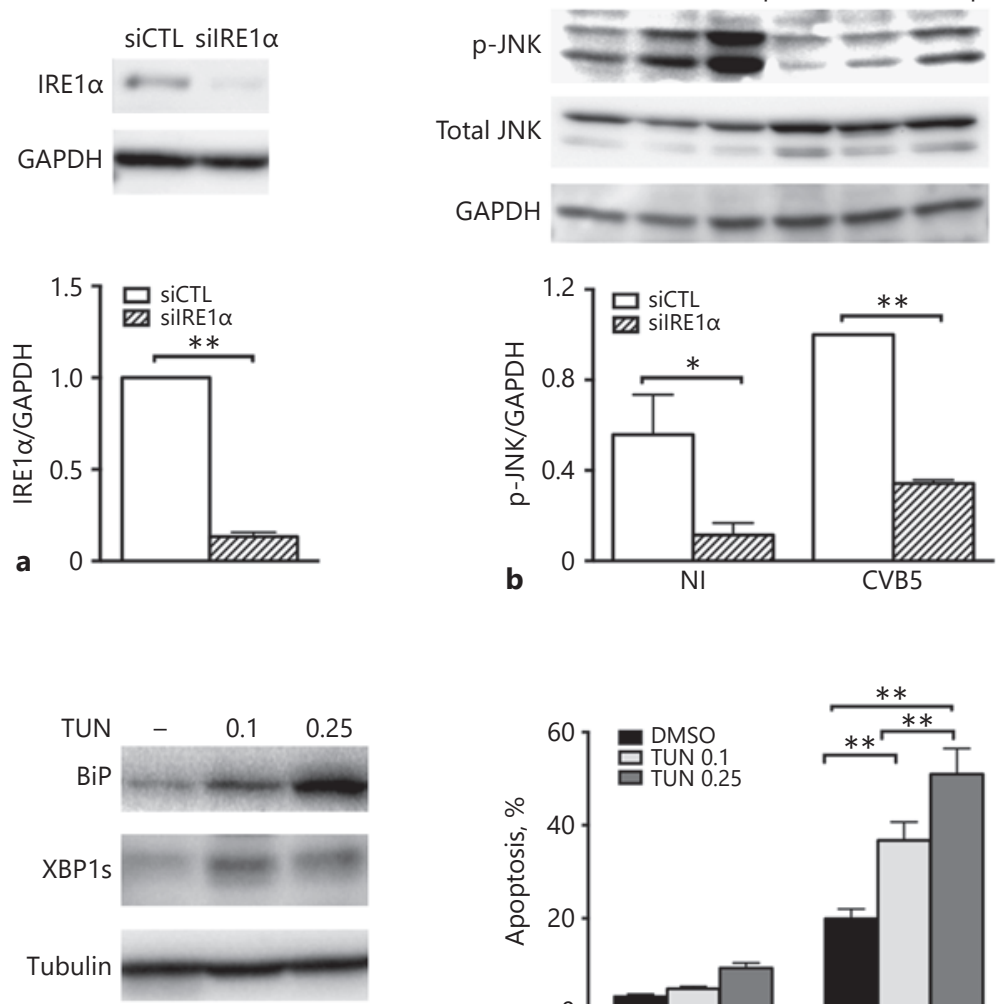

d

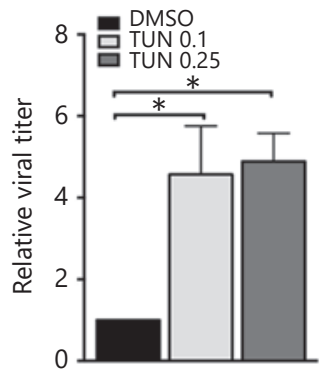

g

Fig. 3. Activation of JNK during viral infection of pancreatic $\beta$ cells is IRE1 $\alpha$-dependent and reduced by the chemical chaperone TUDCA. $\mathbf{a}, \mathbf{b}, \mathbf{h}$ INS-1E cells were transfected with a control siRNA (siCTL) or an siRNA against IRE1a (siIRE1a) for $72 \mathrm{~h}$, and then infected or not with CVB5 at MOI 5 for $14 \mathrm{~h}$. a The efficiency of IRE1 $a$ knockdown was determined at the protein level $(n=3)$. b CVB5-induced activation of JNK was evaluated in the presence or not of IRE1 $\alpha$ silencing. The pro-inflammatory cytokines (IL-1 $\beta$ and IFN- $\gamma$ ) were used as positive control for IRE1 $\alpha$-dependent JNK activation $(n=3)$. c EndoC- $\beta \mathrm{H} 1$ cells were left untreated or pre-treated with TUDCA $(125 \mu \mathrm{M})$ for $24 \mathrm{~h}$. Cells were then infected or not with CVB5, alone or in combination with TUDCA.
Phosphorylation of JNK was determined after $24 \mathrm{~h}$ and quantified by densitometry $(n=4)$. $\mathbf{d}$ Expression of the BiP and XBP1s proteins was evaluated by Western blot after $8 \mathrm{~h}$ of tunicamycin (TUN) treatment. Representative of 3 independent experiments. e-h INS-1E cells were exposed to different doses of tunicamycin for $8 \mathrm{~h}$ and then infected or not with CVB5 for $14 \mathrm{~h}$. e Apoptosis was evaluated using DNA binding dyes $(n=4)$. $\mathbf{f}$ Viral protein expression (VP1) was evaluated by Western blot. Representative of 3 independent experiments. $\mathbf{g}, \mathbf{h}$ Viral amplification is presented as the relative viral titer (described in Methods) $(n=3-5) .{ }^{*} p<0.05$, ** $p<0.01$ vs. the indicated conditions, $t$ test $(\mathbf{a})$, ANOVA $(\mathbf{b}-\mathbf{h})$. Data are mean \pm SEM. 

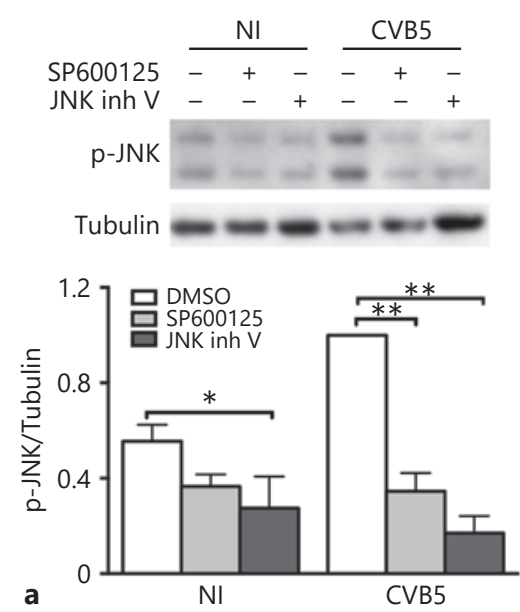

a

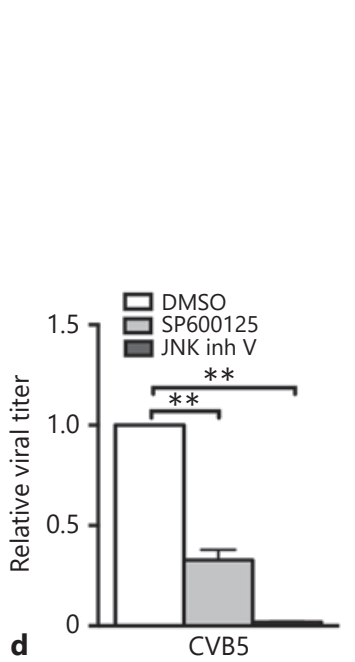

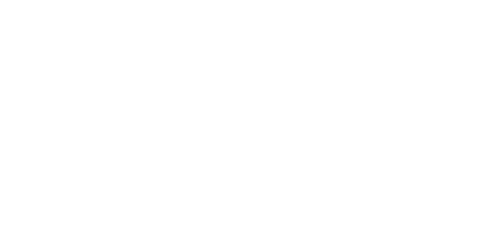
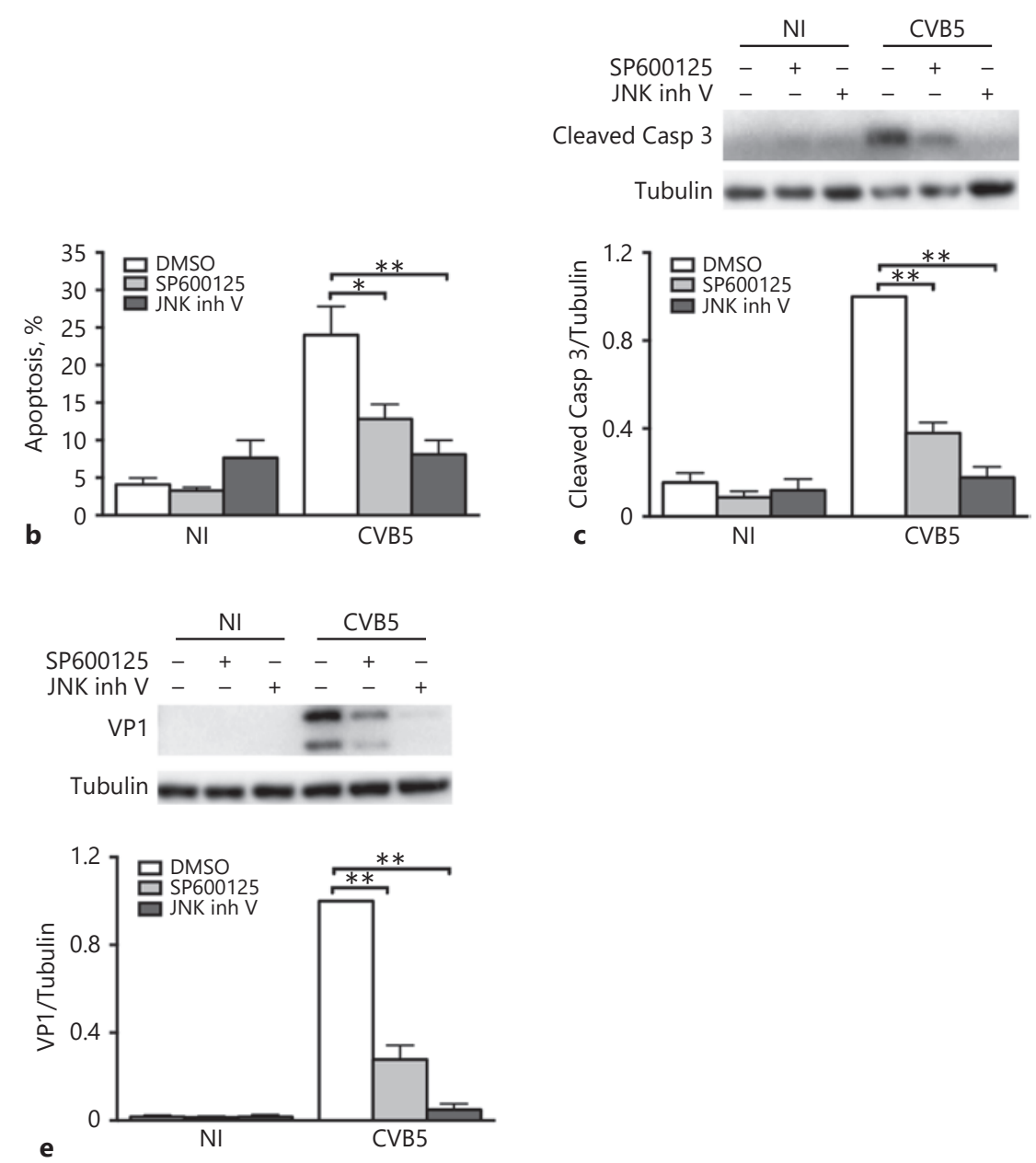

Fig. 4. JNK inhibition reduces CVB5-induced $\beta$ cell apoptosis and viral replication in INS-1E cells. a-e INS-1E cells were infected with CVB5 at MOI 1 for $24 \mathrm{~h}$ in the presence or absence of the chemical JNK inhibitors SP600125 $(10 \mu \mathrm{M})$ or JNK inhibitor V (JNK inh V; $5 \mu \mathrm{M}$ ). a Phosphorylation of JNK was determined by Western blot and quantified by densitometry $(n=3-4)$. b, c Apop- tosis was evaluated using nuclear dyes and cleavage of caspase 3 (Casp 3), was evaluated by Western blot $(n=3-4)$. d Viral replication was quantified by viral titration (described in Methods) $(n=$ 2-4). e VP1 expression was determined by Western blot and quantified by densitometry $(n=3) .{ }^{*} p<0.05,{ }^{* *} p<0.01$ versus the indicated conditions, ANOVA. Data are mean \pm SEM. vation by SP600125 or JNK inhibitor V decreased the viral titers of both viruses by $>60$ and $>90 \%$, respectively (Fig. 4d; online suppl. S5 Fig. D), which is in line with their potency as JNK inhibitors (Fig. 4a; online suppl. S5 Fig. A). JNK inhibition also reduced viral protein expression (Fig. 4e; online suppl. S5 Fig. E). A decrease in virusinduced apoptosis (Fig. 4b, c; online suppl. S5 Fig. B, C) may decrease viral spread and, consequently, the viral progeny. To evaluate if this explained the findings described above, we measured the VP1 expression in the presence or absence of JNK inhibition ahead of the start of apoptosis (at $8 \mathrm{~h}$ ). JNK inhibitors reduced VP1 expression at $6 \mathrm{~h}$ and particularly at $8 \mathrm{~h}$, suggesting that JNK affects viral replication independently of cell death (online suppl. S6 Fig.).

Enteroviruses are human pathogens and there are species-specific responses to viruses [42, 43]. We thus studied the role of JNK phosphorylation on the outcome of viral infection of the human $\beta$ cell line EndoC- $\beta$ H1 (Fig. 5; online suppl. S7 Fig.) and of human pancreatic islets 


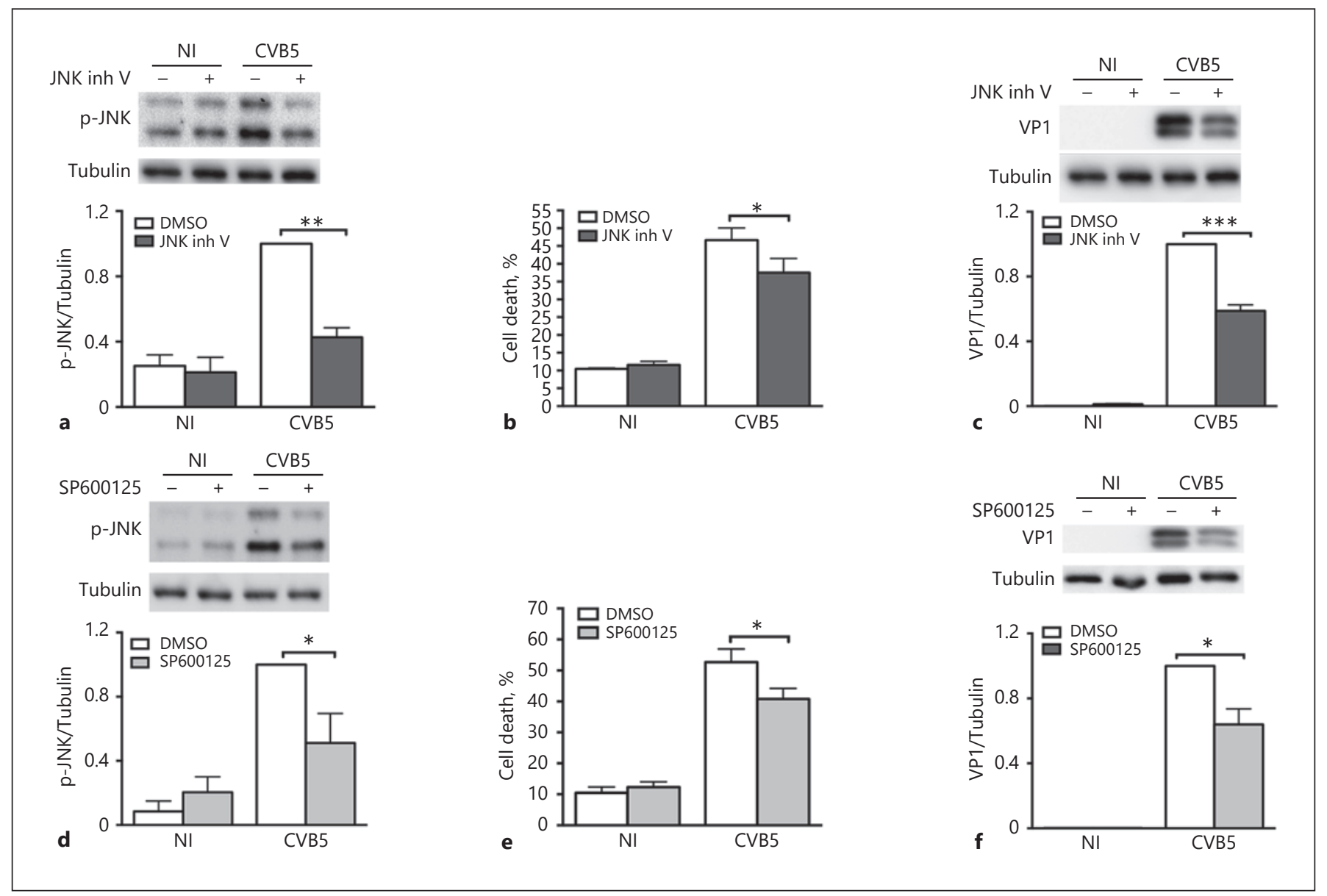

Fig. 5. Prevention of JNK phosphorylation regulates virus-induced cell death and viral protein expression in the human $\beta$ cell line, EndoC- $\beta$ H1. a-f EndoC- $\beta \mathrm{H} 1$ cells were infected or not with CVB5 at MOI 5, alone or in combination with the JNK chemical inhibitors SP600125 (10 $\mu \mathrm{M})$ or JNK inhibitor V (JNK inh V; $5 \mu \mathrm{M})$, for
24 h. a, d JNK activation was determined by Western blot $(n=3)$. b, e Cell viability was quantified using nuclear dyes $(n=4)$. c, f VP1 expression was evaluated by Western blot $(n=3-4) .{ }^{*} p<0.05$, ${ }^{* *} p$ $<0.01$ versus the indicated conditions, ANOVA. Data are mean \pm SEM.
(Fig. 6). In agreement with the findings observed in rat INS-1E cells, inhibition of JNK phosphorylation reduced CVB5- and CVB4-induced cell death in both human EndoC- $\beta \mathrm{H} 1$ cells (Fig. 5b, e; online suppl. S7 Fig. B, E) and primary human islets (Fig. 6a). Furthermore, the JNK inhibitor $\mathrm{V}$ decreased (by $>60 \%$ ) the viral titers in human islets infected with CVB5 or CVB4 (Fig. 6b). This was paralleled by a significant reduction in viral protein expression in CVB5 and CVB4-infected EndoC- $\beta \mathrm{H} 1$ cells (Fig. 5c, f; online suppl. S7 Fig. C, F) and human islets (Fig. 6c, d). Consistently, CVB1 expression is also decreased when EndoC- $\beta \mathrm{H} 1$ cells are infected in the presence of JNK inhibitors (online suppl. S8 Fig.). These results indicate that CVB5, CVB4, and CVB1 amplification require JNK activation.

CVB Tailors UPR in Pancreatic $\beta$ Cells to Favour Viral Amplification
JNK1, but Not JNK2, Regulates Coxsackievirus Replication and Pancreatic $\beta$ Cell Apoptosis

JNK has 2 main isoforms, JNK1 and JNK2 [44]. JNK1 is the main contributor to cytokine-induced $\beta$ cell apoptosis [45]. To clarify the role of these isoforms on viral replication, we used previously validated siRNAs targeting JNK1 or JNK2 $[24,45]$. These siRNAs knocked down JNK1 and JNK2 protein expression by 55 and 65\%, respectively (Fig. 7a, e). As observed using chemical JNK inhibitors (Fig. 4b, c; 5b, e; 6a), silencing JNK1 reduced $\beta$ cell apoptosis after CVB5 infection (Fig. 7b). In addition, JNK1 reduced viral replication, as determined by the quantification of viral titers, and the expression of viral mRNA (data not shown) and protein capsid (Fig. 7c, d). On the other hand, inhibition of JNK2 sensitized pancreatic $\beta$ cells to

Innate Immun 2019;11:375-389 


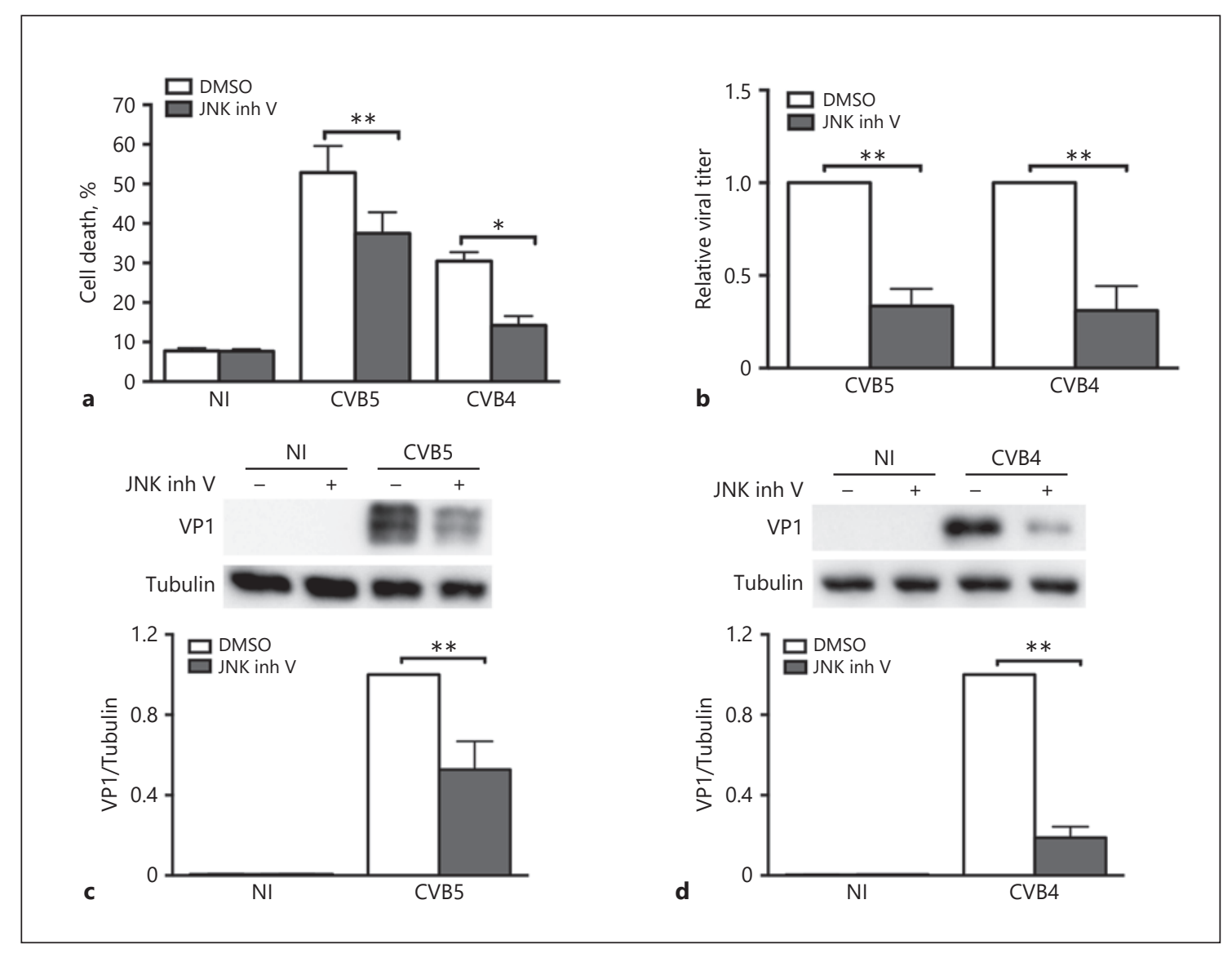

Fig. 6. JNK activation is required for CVB replication and cell death following infection of pancreatic human islets. a-d Dispersed pancreatic human islets were infected with CVB5 or CVB4 at MOI 5 for $24 \mathrm{~h}$, in the presence or not of JNK inhibitor V (JNK inh V; $5 \mu \mathrm{M})$. a Cell viability was quantified using nuclear dyes $(n=5)$. b Viral titers were determined in the presence or absence of JNK inhibitor V $(n=4)$. c, d VP1 expression was evaluated by Western blot $(n=3-4) .{ }^{*} p<0.05,{ }^{* *} p<0.01$ versus the indicated conditions, ANOVA. Data are mean \pm SEM.

virus-induced apoptosis (Fig. 7f) without modifying the viral protein expression or viral titer (Fig. $7 g, h$ ). These data indicate that JNK1 is the main isoform regulating the apoptosis and replication of CVB5 in $\beta$ cells.

\section{Discussion}

We have shown that coxsackievirus infection of pancreatic $\beta$ cells triggers a partial ER stress response. Thus, while the IRE1 $\alpha / \mathrm{XBP} 1 \mathrm{~s}$ branch of the UPR is fully activated, the PERK/eIF2 $\alpha$ and the ATF6/BiP signalling pathways are prematurely arrested. The kinase domain of IRE $1 \alpha$ induces the activation of JNK, which regulates $\beta$ cell apoptosis and virus replication in both rat and human $\beta$ cells. JNK1 is the main isoform regulating $\beta$ cell death and viral replication, whereas JNK2 has predominantly anti-apoptotic effects and does not modify the extent of viral replication.

Pancreatic $\beta$ cells have developed a fine-tuned UPR to cope with the high demand of insulin synthesis, that may reach $50 \%$ of total protein synthesis during stimulation [46]. Many viral infections induce ER stress, but the profile of UPR activation depends on both virus and cell type [47, $48]$. We show here that the infection of $\beta$ cells by coxsackievirus promotes a partial ER stress characterized by an early phosphorylation of the kinase PERK and its downstream target eIF2 $\alpha$, leading to a decrease in protein translation. Picornaviruses, such as CVB, use internal ribosome entry sites (IRES) to initiate their translation. This translation requires canonical translation initiation factors, including eIF2 $\alpha$, for the viral replication [49]. Interestingly, poliovirus (PV), another member of the Picornaviridae family, switches translation from an eIF $2 \alpha$-dependent to an inde- 


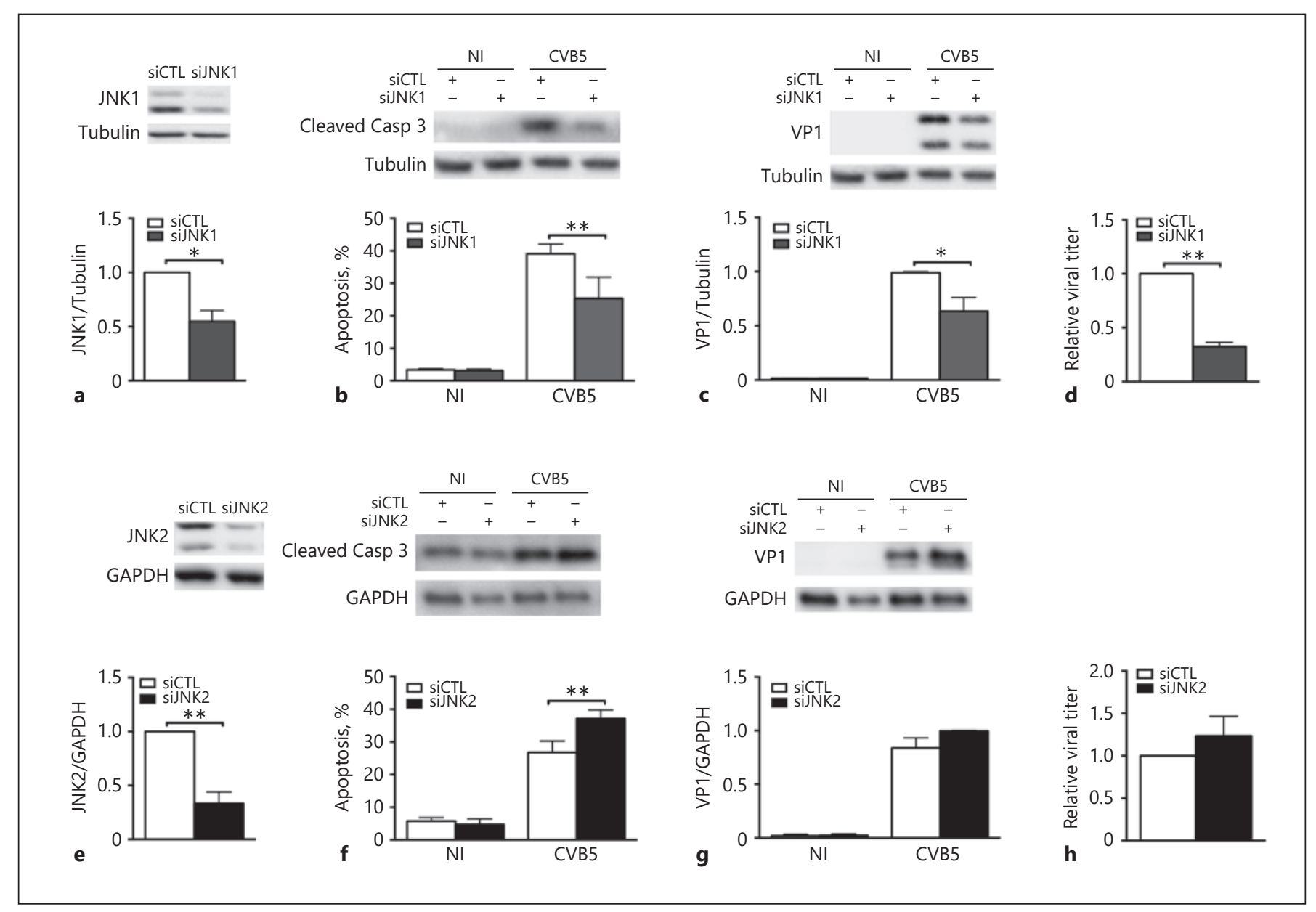

Fig. 7. JNK1 is the main isoform regulating CVB-induced apoptosis and viral replication in pancreatic $\beta$ cells. $\mathbf{a}-\mathbf{h}$ INS-1E cells were transfected with siCTL or specific siRNAs against JNK1 (a-d) or JNK2 (e-h), and, after 48 h of recovery, infected or not with CVB5 at MOI 1 for 24 h. a, e JNK1 and JNK2 knockdown was confirmed by Western blot $(n=4-5)$. b, f Cell viability was measured using nuclear dyes $(n=4-8)$ and confirmed by the activation of caspase

pendent mode during the course of infection [50]. Some of the downstream components of the PERK/eIF2 $\alpha$ signalling pathway have deleterious effects for propagation of the virus, as demonstrated during West Nile virus (WNV) infection, where silencing CHOP expression increases the viral titer and protein expression [51]. The pro-apoptotic protein $\mathrm{CHOP}$ is an important mediator of cytokine-induced $\beta$ cell apoptosis [52]. Our findings suggest that CVB modulates the PERK/eIF $2 \alpha$ branch of the UPR in $\beta$ cells to prevent the early induction of CHOP-dependent early apoptosis, which would be detrimental for CVB replication. Similar UPR tailoring has been described during bacterial infection in other cell types, where LPS prevents

CVB Tailors UPR in Pancreatic $\beta$ Cells to Favour Viral Amplification
3 (Casp 3) in the presence or not of JNK1 or of JNK2 silencing (representative data). c, $\mathbf{g}$ VP1 protein expression was evaluated by Western blot $(n=4-6)$. d, $\mathbf{h}$ Viral titers were determined after silencing or not of JNK1 (d, $n=5)$ or JNK2 (h, $n=3) .{ }^{*} p<0.05$, ** $p<0.01$ vs. the indicated conditions, $t$ test $(\mathbf{a}, \mathbf{d}, \mathbf{e}, \mathbf{h})$, ANOVA $(\mathbf{b}, \mathbf{c}, \mathbf{f}, \mathbf{g})$. Data are mean \pm SEM.

CHOP induction via the TLR/TRIF-dependent pathway [53]. To our knowledge, however, this has not been previously described in viral infections. The mechanisms responsible for this finding remain to be clarified.

Taken as a whole, these observations indicate that CVB5 activation of the UPR eventually leads to the activation of the IRE1 $\alpha / \mathrm{XBP} 1 \mathrm{~s}$ pathway while it inhibits the PERK/ ATF4/ATF3/CHOP pathway. Other authors reported the induction of CHOP and BiP in CVB3-infected HL-1 (a mouse cardiac muscle cell line) and HeLa cells [47, 48]; however, these ER stress markers were not induced in pancreatic human and rat $\beta$ cell lines infected with CVB1, CVB4, or CVB5 (present data). These observations suggest 
Fig. 8. Proposed model for the role of ER stress in coxsackievirus infection of pancreatic $\beta$ cells. During viral infection of $\beta$ cells the IRE1 $\alpha$ signaling pathway is activated, resulting in the generation of the active form of XBP1 (XBP1s) and phosphorylation of the 2 main JNK isoforms, JNK1 and JNK2. Activation of JNK1 contributes to viral replication and cell apoptosis, while JNK2 has anti-apoptotic effects that partly counteract the JNK1 pro-apoptotic effects. Activation of the PERK-eIF2 $\alpha$ pathway is transitory, probably to delay $\beta$ cell apoptosis and thus enable sufficient time for viral amplification.

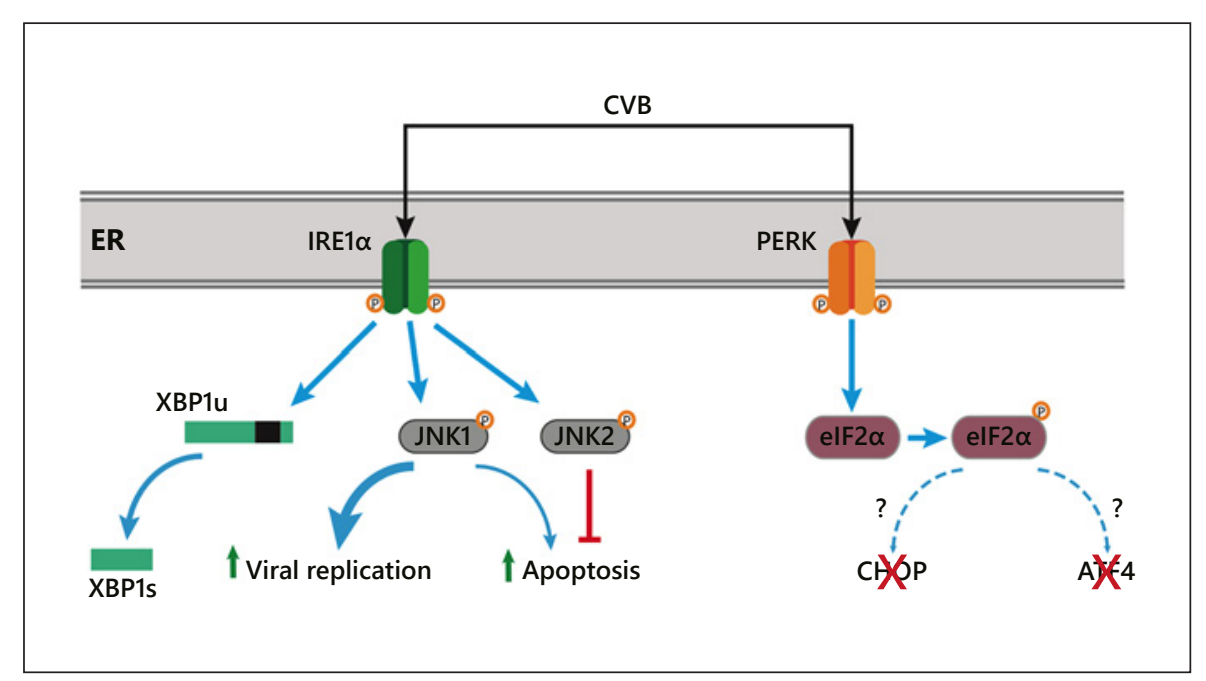

that the particular profile of UPR, i.e., the activation of the pro-viral IRE1 $\alpha /$ PJNK pathway and the blocking of the pro-death PERK/PEIF2 $\alpha / \mathrm{CHOP}$, is putatively specific to CVB-infected $\beta$ cells. Interestingly, the activation of the IRE1 a pathway plays a key role in the onset of diabetes in a mouse model of T1D, namely the non-obese diabetic (NOD) mouse. NOD mice develop spontaneous autoimmune diabetes, which shares many similarities to T1D [54]. ER stress is detected in the $\beta$ cells of NOD mice before the onset of T1D [55]; the treatment of NOD mice with the chemical chaperone TUDCA [56] or imatinib, by blunting IRE1a RNAse hyperactivity, [57] decreases the incidence of diabetes in the T1D mouse model. Selectively activating the IRE1 $\alpha$ pathway, CVB5 could thus trigger $\beta$ cell-directed autoimmunity and demise.

The activation of JNK in enterovirus-infected cells has been previously described in other cell types $[35,58]$ but this was associated with an increase in viral amplification for enterovirus 71 only, by an unknown mechanism [41]. In $\beta$ cells, CVB5 infection induces a significant increase in JNK activation that contributes to the early stages of the viral life cycle, preceding cell death. In line with this, a mild, non-lethal ER stress in $\beta$ cells augments CVB5 proliferation, and this phenomenon is abolished by IRE1 $\alpha$ silencing (our data). It was previously suggested that tunicamycin favours adenoviral entry and thus potentiates adenovirus infection via decreasing the glycosylation of the coxsackievirus and adenovirus receptor (CAR) [59]. Glycosylation of CAR, however, does not affect CVB entry [60]. Moreover, JNK inhibition did not induce differences in viral protein expression at the early time points of CVB5 infection (online suppl. S6 Fig.), and adding JNK inhibitors after CVB5 binding and cell entry had a similar inhibitory effect on viral replication as adding them before viral infection (online suppl. S9 Fig.). Taken together, these findings suggest that JNK does not act via facilitation of the viral entrance, and that tunicamycin favours CVB5 replication in $\beta$ cells by an IRE1 $\alpha$-JNK-dependent mechanism that remains to be identified.

In conclusion, we have shown that potentially diabetogenic viruses, namely CVB1, CVB4, and CVB5, trigger an incomplete UPR response in pancreatic $\beta$ cells (Fig. 8). In this "partial UPR," the pro-apoptotic PERK pathway is arrested, while the IRE1 $a$ pathway is triggered, leading to the activation of kinase JNK1 that is then used by the virus to complete its life cycle. These finding suggest an interesting evolution of the host-virus interaction, where the virus actually takes advantage of a characteristic of pancreatic $\beta$ cells, namely the active UPR response, to proliferate. This novel role for ER stress and the UPR in $\beta$ cell permissiveness to infections by coxsackievirus raises two interesting topics for future research. (1) Childhood obesity accelerates the development of T1D. Since obesity (and the consequent insulin resistance and increased circulating free fatty acids) induces ER stress in $\beta$ cells and contributes to triggering inflammation [3], it will be of great interest to determine whether this also amplifies particular CVB infections in the $\beta$ cells. (2) Modulators of ER stress are being considered as an early therapeutic approach for T1D [3]. It will become relevant to evaluate whether these approaches will also render $\beta$ cells more resistant to viral infections. Enterovirus infections are associated with several diseases. Today, no anti-viral drugs have yet been approved for the treatment of enteroviral infections. ER stress inhibitors and peptide JNK inhibitors are being tested in clinical trials in the context of 
amyotrophic lateral sclerosis or hearing loss, respectively $[61,62]$. Our data, showing the role played by ER stress and JNK activation in CVB amplification, opens the door for the development and testing of new families of molecules for the treatment of enterovirus-associated disease.

\section{Acknowledgement}

The authors are grateful to M.L. Draps, M. Pangerl, A.M. Musuaya, N. Pachera, Y. Cai, M. Depessemier, and I. Millard of the ULB Center for Diabetes Research, Université Libre de Bruxelles, Belgium, for excellent technical support.

\section{Statement of Ethics}

Human islets were isolated from 6 non-diabetic brain-dead organ donors (online suppl. S1 Table) with approval from the local ethics committee in Pisa, Italy. According to Italian legislation, organ and tissue donation in Italy is regulated by Art. 23 of the National Law No. 91, issued on April 1st, 1999; in Tuscany the regional transplant organization (OTT, Organizzazione Toscana Trapianti: http://www.parlamento.it/parlam/leggi/99091l.htm) allows that organs not suitable for clinical transplantation are used for research purposes. Since the donors were brain-dead, provided informed consent was signed by the next-of-kin. Prof. Marchetti's group had access to donated pancreases for the preparation and study of isolated islets on the basis of approval by their local ethics committee, renewed in 2013. The use of the human islets for our research project was also been approved by the Ethics Committee of the Université Libre de Bruxelles and Erasmus Hospital, Belgium.

\section{Disclosure Statement}

The authors have no conflicts of interest to declare.

\section{Funding Sources}

This work was supported by grants from the Horizon 2020 Program T2Dsystems (GA667191) to D.L.E. (https://ec.europa.eu/ programmes/horizon2020/). D.L.E. and P.M. have received funding from the Innovative Medicines Initiative 2 Joint Undertaking, under grant agreement No. 115797 (INNODIA) (https://innodia. $\mathrm{eu}$. This joint undertaking receives support from the Union's Horizon 2020 research and innovation programme and "EFPIA," "JDRF," and "The Leona M. and Harry B. Helmsley Charitable Trust." A.O.d.b. received funding from the Fonds Emile Defay (http://www.ulb.ac.be/recherche/mv/defay.html). The funders had no role in study design, data collection and analysis, decision to publish, or preparation of the manuscript.

\section{Author Contributions}

M.L.C., D.L.E. and A.O.d.b. conceived, designed, and supervised the experiments. M.L.C., F.M.P. and A.O.d.b. acquired data. L.M., P.M., and M.R. contributed with material and reagents. M.L.C., D.L.E. and A.O.d.b. wrote the manuscript. All authors revised the manuscript. A.O.d.b. is the guarantor of this work and, as such, has full access to all the data in the study and takes responsibility for the integrity of the data and the accuracy of the data analysis.

\section{References}

1 Yokota S, Okabayashi T, Fujii N. The battle between virus and host: modulation of Tolllike receptor signaling pathways by virus infection. Mediators Inflamm. 2010;2010: 184328.

2 Fung TS, Torres J, Liu DX. The Emerging Roles of Viroporins in ER Stress Response and Autophagy Induction during Virus Infection. Viruses. 2015 Jun;7(6):2834-57.

3 Eizirik DL, Miani M, Cardozo AK. Signalling danger: endoplasmic reticulum stress and the unfolded protein response in pancreatic islet inflammation. Diabetologia. 2013 Feb;56(2): 234-41.

4 Lee AH, Iwakoshi NN, Glimcher LH. XBP-1 regulates a subset of endoplasmic reticulum resident chaperone genes in the unfolded protein response. Mol Cell Biol. 2003 Nov;23(21): 7448-59.

5 Urano F, Wang X, Bertolotti A, Zhang Y, Chung P, Harding HP, et al. Coupling of stress in the ER to activation of JNK protein kinases by transmembrane protein kinase IRE1. Science. 2000 Jan;287(5453):664-6.
6 Li M, Baumeister P, Roy B, Phan T, Foti D, Luo S, et al. ATF6 as a transcription activator of the endoplasmic reticulum stress element: thapsigargin stress-induced changes and synergistic interactions with NF-Y and YY1. Mol Cell Biol. 2000 Jul;20(14):5096-106.

7 Vattem KM, Wek RC. Reinitiation involving upstream ORFs regulates ATF4 mRNA translation in mammalian cells. Proc Natl Acad Sci USA. 2004 Aug;101(31):11269-74.

8 Eizirik DL, Colli ML, Ortis F. The role of inflammation in insulitis and beta-cell loss in type 1 diabetes. Nat Rev Endocrinol. 2009 Apr;5(4):219-26.

9 Hyöty H. Viruses in type 1 diabetes. Pediatr Diabetes. 2016 Jul;17 Suppl 22:56-64.

10 Looney BM, Xia CQ, Concannon P, Ostrov DA, Clare-Salzler MJ. Effects of type 1 diabetes-associated IFIH1 polymorphisms on MDA5 function and expression. Curr Diab Rep. 2015 Nov;15(11):96.
11 Domsgen E, Lind K, Kong L, Hühn MH, Rasool $\mathrm{O}$, van Kuppeveld F, et al. An IFIH1 gene polymorphism associated with risk for autoimmunity regulates canonical antiviral defence pathways in Coxsackievirus infected human pancreatic islets. Sci Rep. 2016 Dec;6(1):39378.

12 Colli ML, Nogueira TC, Allagnat F, Cunha DA, Gurzov EN, Cardozo AK, et al. Exposure to the viral by-product dsRNA or Coxsackievirus $B 5$ triggers pancreatic beta cell apoptosis via a Bim / Mcl-1 imbalance. PLoS Pathog. 2011 Sep;7(9):e1002267.

13 Richardson SJ, Willcox A, Bone AJ, Foulis AK, Morgan NG. The prevalence of enteroviral capsid protein vp1 immunostaining in pancreatic islets in human type 1 diabetes. Diabetologia. 2009 Jun;52(6):1143-51.

14 Tracy S, Smithee S, Alhazmi A, Chapman N. Coxsackievirus can persist in murine pancreas by deletion of $5^{\prime}$ terminal genomic sequences. J Med Virol. 2015 Feb;87(2):240-7.

15 Clark AL, Urano F. Endoplasmic reticulum stress in beta cells and autoimmune diabetes. Curr Opin Immunol. 2016 Dec;43:60-6. 
16 Asfari M, Janjic D, Meda P, Li G, Halban PA, Wollheim CB. Establishment of 2-mercaptoethanol-dependent differentiated insulin-secreting cell lines. Endocrinology. 1992 Jan; 130(1):167-78.

17 Ravassard P, Hazhouz Y, Pechberty S, Bricout-Neveu E, Armanet M, Czernichow P, et al. A genetically engineered human pancreatic $\beta$ cell line exhibiting glucose-inducible insulin secretion. J Clin Invest. 2011 Sep;121(9): 3589-97.

18 Brozzi F, Nardelli TR, Lopes M, Millard I, Barthson J, Igoillo-Esteve M, et al. Cytokines induce endoplasmic reticulum stress in human, rat and mouse beta cells via different mechanisms. Diabetologia. 2015 Oct;58(10): 2307-16.

19 Marchetti P, Bugliani M, Lupi R, Marselli L, Masini M, Boggi U, et al. The endoplasmic reticulum in pancreatic beta cells of type 2 diabetes patients. Diabetologia. 2007 Dec;50(12): 2486-94.

20 Eizirik DL, Sammeth M, Bouckenooghe T, Bottu G, Sisino G, Igoillo-Esteve M, et al. The human pancreatic islet transcriptome: expression of candidate genes for type 1 diabetes and the impact of pro-inflammatory cytokines. PLoS Genet. 2012;8(3):e1002552.

21 Nair S, Leung KC, Rawlinson WD, Naing Z, Craig ME. Enterovirus infection induces cytokine and chemokine expression in insulinproducing cells. J Med Virol. 2010 Nov; 82(11):1950-7.

22 Lennette EH. General principles underlying laboratory diagnosis of viral and rickettsial infections. In: Lennette EH, Schmidt NJ, editors. Diagnostic Procedures for Viral and Rickettsial Diseases. 3rd ed. New York: American Public Health Association. 1979. p. 1-63.

23 Santin I, Moore F, Colli ML, Gurzov EN, Marselli L, Marchetti P, et al. PTPN2, a candidate gene for type 1 diabetes, modulates pancreatic $\beta$-cell apoptosis via regulation of the BH3-only protein Bim. Diabetes. 2011 Dec; 60(12):3279-88.

24 Abdelli S, Puyal J, Bielmann C, Buchillier V, Abderrahmani A, Clarke PG, et al. JNK3 is abundant in insulin-secreting cells and protects against cytokine-induced apoptosis. Diabetologia. 2009 Sep;52(9):1871-80.

25 Miani M, Colli ML, Ladrière L, Cnop M, Eizirik DL. Mild endoplasmic reticulum stress augments the proinflammatory effect of IL- $1 \beta$ in pancreatic rat $\beta$-cells via the IRE1 $\alpha /$ $\mathrm{XBP} 1 s$ pathway. Endocrinology. 2012 Jul; 153(7):3017-28.

26 Moore F, Naamane N, Colli ML, Bouckenooghe T, Ortis F, Gurzov EN, et al. STAT1 is a master regulator of pancreatic $\{$ beta\}-cell apoptosis and islet inflammation. J Biol Chem. 2011 Jan;286(2):929-41.

27 Cunha DA, Hekerman P, Ladrière L, BazarraCastro A, Ortis F, Wakeham MC, et al. Initiation and execution of lipotoxic ER stress in pancreatic beta-cells. J Cell Sci. 2008 Jul; 121(Pt 14):2308-18.
28 Rasschaert J, Ladrière L, Urbain M, Dogusan Z, Katabua B, Sato S, et al. Toll-like receptor 3 and STAT-1 contribute to double-stranded RNA+ interferon-gamma-induced apoptosis in primary pancreatic beta-cells. J Biol Chem. 2005 Oct;280(40):33984-91.

29 Overbergh L, Valckx D, Waer M, Mathieu C. Quantification of murine cytokine mRNAs using real time quantitative reverse transcriptase PCR. Cytokine. 1999 Apr;11(4):305-12.

30 Marroqui L, Lopes M, dos Santos RS, Grieco FA, Roivainen M, Richardson SJ, et al. Differential cell autonomous responses determine the outcome of coxsackievirus infections in murine pancreatic $\alpha$ and $\beta$ cells. eLife. 2015 Jun;4:e06990.

31 Roivainen M, Rasilainen S, Ylipaasto P, Nissinen R, Ustinov J, Bouwens L, et al. Mechanisms of coxsackievirus-induced damage to human pancreatic beta-cells. J Clin Endocrinol Metab. 2000 Jan;85(1):432-40.

32 Wagenknecht LE, Roseman JM, Herman $\mathrm{WH}$. Increased incidence of insulin-dependent diabetes mellitus following an epidemic of Coxsackievirus B5. Am J Epidemiol. 1991 May;133(10):1024-31.

33 Ammendrup A, Maillard A, Nielsen K, Aabenhus Andersen N, Serup P, Dragsbaek Madsen $\mathrm{O}$, et al. The c-Jun amino-terminal kinase pathway is preferentially activated by interleukin- 1 and controls apoptosis in differentiating pancreatic beta-cells. Diabetes. 2000 Sep;49(9):1468-76.

34 Cunha DA, Igoillo-Esteve M, Gurzov EN, Germano CM, Naamane N, Marhfour I, et al. Death protein 5 and p53-upregulated modulator of apoptosis mediate the endoplasmic reticulum stress-mitochondrial dialog triggering lipotoxic rodent and human $\beta$-cell apoptosis. Diabetes. 2012 Nov;61(11):276375.

35 Kim SM, Park JH, Chung SK, Kim JY, Hwang $\mathrm{HY}$, Chung KC, et al. Coxsackievirus B3 infection induces cyr61 activation via JNK to mediate cell death. J Virol. 2004 Dec;78(24): 13479-88.

36 Engin F, Hotamisligil GS. Restoring endoplasmic reticulum function by chemical chaperones: an emerging therapeutic approach for metabolic diseases. Diabetes Obes Metab. 2010 Oct;12 Suppl 2:108-15.

37 Colli ML, Moore F, Gurzov EN, Ortis F, Eizirik DL. MDA5 and PTPN2, two candidate genes for type 1 diabetes, modify pancreatic beta-cell responses to the viral by-product double-stranded RNA. Hum Mol Genet. 2010 Jan;19(1):135-46.

38 Dotta F, Censini S, van Halteren AG, Marselli L, Masini M, Dionisi S, et al. Coxsackie $\mathrm{B} 4$ virus infection of beta cells and natural killer cell insulitis in recent-onset type 1 diabetic patients. Proc Natl Acad Sci USA. 2007 Mar;104(12):5115-20.
39 Ceballos-Olvera I, Chávez-Salinas S, Medina F, Ludert JE, del Angel RM. JNK phosphorylation, induced during dengue virus infection, is important for viral infection and requires the presence of cholesterol. Virology. 2010 Jan;396(1):30-6.

40 Zhang S, Tian H, Cui J, Xiao J, Wang M, Hu Y. The c-Jun $\mathrm{N}$-terminal kinase (JNK) is involved in $\mathrm{H} 5 \mathrm{~N} 1$ influenza $\mathrm{A}$ virus RNA and protein synthesis. Arch Virol. 2016 Feb; 161(2):345-51.

41 Peng H, Shi M, Zhang L, Li Y, Sun J, Zhang L, et al. Activation of JNK1/2 and p38 MAPK signaling pathways promotes enterovirus 71 infection in immature dendritic cells. BMC Microbiol. 2014 Jun;14(1):147.

42 Barreiro LB, Marioni JC, Blekhman R, Stephens M, Gilad Y. Functional comparison of innate immune signaling pathways in primates. PLoS Genet. 2010 Dec;6(12):e1001249.

43 Mandl JN, Ahmed R, Barreiro LB, Daszak P, Epstein JH, Virgin HW, et al. Reservoir host immune responses to emerging zoonotic viruses. Cell. 2015 Jan;160(1-2):20-35.

44 Zeke A, Misheva M, Reményi A, Bogoyevitch MA. JNK Signaling: Regulation and Functions Based on Complex Protein-Protein Partnerships. Microbiol Mol Biol Rev. 2016 Jul;80(3):793-835.

45 Marroquí L, Santin I, Dos Santos RS, Marselli L, Marchetti P, Eizirik DL. BACH2, a candidate risk gene for type 1 diabetes, regulates apoptosis in pancreatic $\beta$-cells via JNK1 modulation and crosstalk with the candidate gene PTPN2. Diabetes. 2014 Jul;63(7):2516-27.

46 Eizirik DL, Cardozo AK, Cnop M. The role for endoplasmic reticulum stress in diabetes mellitus. Endocr Rev. 2008 Feb;29(1):42-61.

47 Zhang HM, Ye X, Su Y, Yuan J, Liu Z, Stein DA, et al. Coxsackievirus B3 infection activates the unfolded protein response and induces apoptosis through downregulation of p58IPK and activation of CHOP and SREBP 1 . J Virol. 2010 Sep;84(17):8446-59.

48 Liu Z, Zhang HM, Yuan J, Ye X, Taylor GA, Yang D. The immunity-related GTPase Irgm3 relieves endoplasmic reticulum stress response during coxsackievirus $\mathrm{B} 3$ infection via a PI3K/Akt dependent pathway. Cell Microbiol. 2012 Jan;14(1):133-46.

49 Gerlitz G, Jagus R, Elroy-Stein O. Phosphorylation of initiation factor- $2 \alpha$ is required for activation of internal translation initiation during cell differentiation. Eur J Biochem. 2002 Jun;269(11):2810-9.

50 White JP, Reineke LC, Lloyd RE. Poliovirus switches to an eIF2-independent mode of translation during infection. J Virol. 2011 Sep; 85(17):8884-93.

51 Medigeshi GR, Lancaster AM, Hirsch AJ, Briese T, Lipkin WI, Defilippis V, et al. West Nile virus infection activates the unfolded protein response, leading to $\mathrm{CHOP}$ induction and apoptosis. J Virol. 2007 Oct;81(20):10849-60. 
52 Allagnat F, Fukaya M, Nogueira TC, Delaroche D, Welsh N, Marselli L, et al. C/EBP homologous protein contributes to cytokineinduced pro-inflammatory responses and apoptosis in $\beta$-cells. Cell Death Differ. 2012 Nov; 19(11):1836-46.

53 Woo CW, Cui D, Arellano J, Dorweiler B, Harding H, Fitzgerald KA, et al. Adaptive suppression of the ATF4-CHOP branch of the unfolded protein response by toll-like receptor signalling. Nat Cell Biol. 2009 Dec; 11(12):1473-80.

54 Anderson MS, Bluestone JA. The NOD mouse: a model of immune dysregulation. Annu Rev Immunol. 2005;23(1):447-85.

55 Tersey SA, Nishiki Y, Templin AT, Cabrera SM, Stull ND, Colvin SC, et al. Islet $\beta$-cell endoplasmic reticulum stress precedes the onset of type 1 diabetes in the nonobese diabetic mouse model. Diabetes. 2012 Apr;61(4):81827.
56 Engin F, Yermalovich A, Nguyen T, Hummasti S, Fu W, Eizirik DL, et al. Restoration of the unfolded protein response in pancreatic $\beta$ cells protects mice against type 1 diabetes. Sci Transl Med. 2013 Nov;5(211):211ra156.

57 Morita S, Villalta SA, Feldman HC, Register AC, Rosenthal W, Hoffmann-Petersen IT, et al. Targeting ABL-IRE1a Signaling Spares ER-Stressed Pancreatic $\beta$ Cells to Reverse Autoimmune Diabetes. Cell Metabol. 2017;25: $883-97$.

58 Si X, Luo H, Morgan A, Zhang J, Wong J, Yuan J, et al. Stress-activated protein kinases are involved in coxsackievirus B3 viral progeny release. J Virol. 2005 Nov;79(22):1387581.

59 Excoffon KJ, Gansemer N, Traver G, Zabner J. Functional effects of coxsackievirus and adenovirus receptor glycosylation on homophilic adhesion and adenoviral infection. J Virol. 2007 Jun;81(11):5573-8.
60 Pinkert S, Röger C, Kurreck J, Bergelson JM, Fechner H. The Coxsackievirus and Adenovirus Receptor: Glycosylation and the Extracellular D2 Domain Are Not Required for Coxsackievirus B3 Infection. J Virol. 2016 May; 90(12):5601-10.

61 Eshraghi AA, Aranke M, Salvi R, Ding D, Coleman JK Jr, Ocak E, et al. Preclinical and clinical otoprotective applications of cellpenetrating peptide D-JNKI-1 (AM-111). Hear Res. 2018 Oct;368:86-91.

62 Elia AE, Lalli S, Monsurrò MR, Sagnelli A, Taiello AC, Reggiori B, et al. Tauroursodeoxycholic acid in the treatment of patients with amyotrophic lateral sclerosis. Eur J Neurol. 2016 Jan;23(1):45-52. 